\title{
The Floristic Composition of Irrigation Ponds and Water Reservoirs in Albania after the Long Persistent Drought of 2016-2017
}

\author{
Attila Rigó ${ }^{{ }^{*}}$ and Zoltán Barina ${ }^{2}$ \\ 1 Department of Nature Conservation \& Landscape Ecology, Hungarian University of Agriculture and Life \\ Sciences, Gödöllő, Hungary; rigo.attila@hallgato.uni-szie.hu \\ 2 H-1095 Budapest, Ipar utca 3., Hungary; quercusbz@gmail.com \\ * Correspondence: rigo.attila@hallgato.uni-szie.hu
}

\begin{abstract}
The occurrence of temporary wetland habitats was once frequent in Europe, especially in the Mediterranean region, but attenuating nowadays. The role of anthropogenic aquatic habitats (such as irrigation ponds) in biodiversity and nature conservation has recently become more important. Small irrigation ponds and greater water reservoirs are common parts of the landscape in Albania. The persistent drought of 2016-2017 allowed us to explore the floristic diversity of the beds of dried irrigation ponds and reservoirs. The timing of the field survey was early autumn based on knowledge of the expected appearance of mud vegetation. We recorded the physical parameters of the ponds (location, altitude, the slope angle of the embankment, and bedrock). The cover of each species, water surface, and mud has been estimated by circuiting the whole reservoir. Altogether 129 ponds and reservoirs were studied, more than 3400 new floristic records referring to 324 vascular plant species (of which 35 are adventive) were recorded. Most of the dried irrigation ponds were rather sparsely colonized. Irrigation ponds can serve as a refuge for plants that are connected to wet habitats, but grazing and manuring in and around them can be a threat by promoting the spread of invasive and nitrophilous plants.
\end{abstract}

Keywords: Albania; anthropogenic aquatic habitats; invasive plant species; irrigation pond; mud vegetation; water reservoir

\section{Introduction}

The abundance and biodiversity of natural aquatic ecosystems is decreasing [1]. The occurrence of temporary wetland habitats was once frequent in Europe, especially in the Mediterranean region, but attenuating nowadays [2]. Man-made aquatic ecosystems (e.g. irrigation ponds, water reservoirs) can be a refuge for plant and animal communities that are connected to aquatic habitats [3]. The role of these small artificial water bodies in biodiversity and nature conservation is important [4]. Besides being a refuge, these anthropogenic sites can be a threat by providing habitat to invasive plants [5].

Mud vegetation can be developed on the dried beds of artificial water bodies [6]. Exposed mudflats are nutrient-rich ephemerous habitats with favourable edaphic conditions, thus pioneer mudflat species are usually short-lived annuals, which are germinating almost simultaneously and finish their life cycle in a very short time (only few weeks) if the circumstances (decreasing water level) allow it [7-8]. There are numerous publications worldwide that aim to study the vegetation in anthropogenic wetland sites [7, 9-11]. The review of Deil [8] summarized our knowledge on ephemeral wetland habitats around the world (including anthropogenic ephemeral wetlands).

Albania is rich in waters, there are 152 rivers and streams, 247 natural lakes and about 800 artificial water reservoirs (in Albanian: rezervuar) and ponds (in Albanian: pellg) [12]. The artificial water reservoirs and irrigation ponds - according to their size - have major role in flood protection, 
producing hydro-power, water supply and irrigation in agriculture [13]. The persistent drought of 2017 in Albania [14] offered us an opportunity to examine the mud vegetation on the dried bottoms of different-sized irrigation ponds and water reservoirs. There were some remarkable findings in reservoirs on previous expeditions [15], but their flora has not been systematically studied previously as far as we know.

The aim of our research was to explore the floristic and habitat diversity of these ephemeral stands and evaluate their biogeographical and nature conservation role. The main questions of our research were the followings: (1) What are the ecological requirements and life forms of the plants that colonize water reservoirs? (2) Are there alien species in the reservoirs and what is their role when compared to native species? (3) Do the type of bedrock, the size, the altitude, the range of water surface or the biogeographical environment have any effect on the composition of the flora of water reservoirs? (4) Do reservoirs have a significant role in nature conservation by conserving some rare species?

\section{Materials and methods}

\subsection{Study areas}

Altogether 129 different sized water reservoirs from almost all regions of Albania were involved in the research. We located water reservoirs by using geoinformatics (Google Earth and QGis). Only artificially dammed water bodies (water reservoirs and irrigation ponds) were included in the research, the research was restricted to the strict territory of reservoirs (up to the possible water level). We excluded natural lakes, quarry ponds and tarns. The field work was achieved between 4 th and 14th September 2017. The following data has been recorded for each reservoir: exact location (vicinity, GPS coordinates, altitude), gradient interval, size, type of bedrock, ratio of water surface, bare soil (mud), vegetation and composing taxa. Each reservoir was photodocumented.

\subsection{Floristic procedures}

The ratio of each species, water surface and mud surface has been estimated by circuiting the whole reservoir, no random plots have been established. For the identification of the species we used [16-26]. Nomenclature follows [15].

\subsection{Data management and mapping solutions}

We used Google Earth to track the loss of water of each reservoirs and ponds, as for most reservoirs, images of both wet and dry periods are available. We recorded the bedrock type on the field, and the field observations were specified by using the geological map of Albania. The gradient intervals of the slope angles of the reservoir dams were estimated in the field.

\section{Results}

\subsection{General results}

During the field research we carried out floristic surveys of 129 reservoirs in 9 of the 12 counties of Albania, the distribution of the surveyed reservoirs by region is not uniform (Table 1.). Based on the total dimensions (before drying) of the reservoirs, the visited reservoirs show a large variation in size, but the vast majority of the reservoirs have an area of less than 10 hectares (Table 2.). The altitude of the reservoirs varies from 11 to $1030 \mathrm{~m}$ a.s.l., $38.8 \%$ of them are located below $200 \mathrm{~m}$ a.s.1., $27.1 \%$ between 200 and $600 \mathrm{~m}$ a.s.l., while $34.1 \%$ above $600 \mathrm{~m}$ a.s.l. More than $2 / 3$ of the surveyed reservoirs were on some sedimentary rock, a total of 41 reservoirs were on flysch, 11 on limestone, and 36 on other, younger sediments. The remaining one-third is roughly evenly distributed among the following categories: serpentine, sand and clay (Table 3.). One of the reservoirs were on andesite bedrock. The water level and drying degree of reservoirs show significant variance, only 10 reservoirs 
were fully dried and 5 reservoirs were full of water. However, a significant proportion of reservoirs were at some degree of drying.

Table 1. Distribution of reservoirs by county.

\begin{tabular}{cc}
\hline County & No. of reservoirs \\
\hline Dibër & 25 \\
Shkodër & 5 \\
Lezhë & 8 \\
Durrës & 12 \\
Elbasan & 16 \\
Korçë & 25 \\
Tirana & 13 \\
Fier & 7 \\
Gjirokastër & 18 \\
\hline
\end{tabular}

Table 2. Size of the surveyed reservoirs.

\begin{tabular}{cc}
\hline $\begin{array}{c}\text { Full size of } \\
\text { reservoir (ha) }\end{array}$ & No. of reservoirs \\
\hline$<0,1$ & 15 \\
$0,1-1$ & 23 \\
$1-10$ & 51 \\
$10-100$ & 36 \\
$100-1000$ & 2 \\
$>1000$ & 2 \\
\hline
\end{tabular}

Table 3. Distribution of reservoirs by bedrock.

\begin{tabular}{cc}
\hline Bedrock & No. of reservoirs \\
\hline Flysch & 41 \\
Other sediments & 36 \\
Sand & 14 \\
Serpentine & 13 \\
Clay & 13 \\
Limestone & 11 \\
Andesite & 1 \\
\hline
\end{tabular}

\subsection{New distribution records}

We have found 4 new species for Albania, these are: Ammannia coccinea Rottb., Dysphania pumilio (R.Br.) Mosyakin \& Clemants, Lindernia procumbens (Krock.) Philcox and Verbena supina L. [27], and confirmed the presence of Cyperus serotinus Rottb. in Albania. The latter has been found in the reed of an irrigation pond near Renc (Shkodër county). We also found a new locality for Oldenlandia capensis L., a plant native in Africa and the Middle-East, and within Europe so far only found on the muddy shores of Shkodra Lake. The plant was found in a reservoir near Shkodër, not far from its formerly known occurrences on the mud of Lake Shkodra and some surrounding reservoirs.

Our knowledge on the distribution of several rare species in Albania has expanded. One such species is Chenopodium rubrum L., which has so far had 2 occurrence data from Albania, but 10 new localities have also been found in the research. The survey evinced the inland occurrence of Eclipta prostrata (L.) L. - a rarely naturalized plant Albania - the plant had only 2 known localities near the seashores, but we have found it in 7 inland reservoirs. 
In the case of some species that are under-mapped in [15], it can be stated that, contrary to our previous knowledge, they are not uncommon in Albania. Such a species is, for example, Conyza bonariensis (L.) Cronquist, a species naturalized in Albania, was found in the mud vegetation of 24 reservoirs during the research and was first found in the eastern part of the country. Euphorbia chymaesyce L. previously had only 2 known occurrences in Albania, however we have found the species in more than 30 reservoirs, this species is probably also not uncommon in Albania.

\subsection{Vegetation character}

As a result of the research, 3473 floristic data referring to 324 vascular plant species were collected. Of the species found, 35 are non-native in Albania (17.8\% of the alien species found in the country). In addition to 161 annual species, 163 perennial plant species were found. On average we found 25.9 species per reservoir. The maximum number of species per reservoir were 76 , but there were 3 reservoirs without any terrestrial vegetation. A total of 124 species were found only in one reservoir. Most of the reservoirs were rather sparsely colonized, in 119 reservoirs the coverage of vegetation was less than $30 \%$ and maximum $90 \%$ of a reservoir was covered with vegetation. The presence of cultivated plants in the reservoirs was prominent, 7 (edible) cultivated species (e. g. Citrullus lanatus (Thunb.) Matsum. \& Nakai) appeared as casual ephemers on the dried bed of reservoirs. The species found in the reservoirs belong to 55 plant families. Asteraceae, Poaceae and Fabaceae are represented by the largest number of species. Of the 10 most common species registered, all occur in more than $40 \%$ of reservoirs and 6 of them in more than half of the reservoirs (Table 4.). Of the most common species, there is only one adventive plant, Paspalum paspalodes (Michx.) Scribn. The floristic composition of reservoirs established on different bedrocks is slightly different (Table 5.). There is significant overlap between the most common species. Significant differences can be observed only in the case of the flora of reservoirs formed on serpentine, sand and clay in terms of the most common species.

Table 4. The 10 most common species found in water reservoirs in Albania

\begin{tabular}{cc}
\hline Species & $\begin{array}{c}\text { Found in \% } \\
\text { of reservoirs }\end{array}$ \\
\hline Mentha pulegium & 58.91 \\
Echinochloa crus-galli & 57.36 \\
Cynodon dactylon & 57.36 \\
Polygonum lapathifolium & 55.04 \\
Portulaca oleracea & 52.71 \\
Verbena officinalis & 50.39 \\
Paspalum paspaloides & 49.61 \\
Digitaria sanguinalis & 48.84 \\
Plantago major & 41.86 \\
Polygonum aviculare & 41.86 \\
\hline
\end{tabular}

Table 5. The 20 most common species on different substrates

\begin{tabular}{cccc}
\hline Serpentine & \multicolumn{3}{c}{ Found in \% of } \\
Species & Species & $\begin{array}{c}\text { Found in \% of } \\
\text { reservoirs }\end{array}$ \\
\hline Cyperus fuscus & 69.23 & Plantago major & 54.55 \\
Cynodon dactylon & 61.54 & Echinochloa crus-galli & 45.45 \\
Digitaria sanguinalis & 61.54 & Typha angustifolia & 45.45 \\
Echinochloa crus-galli & 61.54 & Eleocharis palustris & 36.36 \\
Paspalum paspaloides & 61.54 & Equisetum palustre & 36.36 \\
\hline
\end{tabular}

The 1st International Electronic Conference on Biological Diversity, Ecology, and Evolution, 15-31 March 2021 


\begin{tabular}{|c|c|c|c|}
\hline Polygonum lapathifolium & 61.54 & Mentha pulegium & 36.36 \\
\hline Portulaca oleracea & 53.85 & Heleochloa schoenoides & 36.36 \\
\hline Bidens tripartita & 46.15 & Polygonum lapathifolium & 36.36 \\
\hline Juncus articulatus & 46.15 & Portulaca oleracea & 36.36 \\
\hline Inula britannica & 38.46 & Potamogeton pectinatus & 36.36 \\
\hline Eleocharis palustris & 38.46 & Verbena officinalis & 36.36 \\
\hline Euphorbia chamaesyce & 38.46 & Alisma lanceolatum & 27.27 \\
\hline Polygonum aviculare & 38.46 & Xanthium strumarium & 27.27 \\
\hline Holoschoenus romanus & 30.77 & Inula viscosa & 27.27 \\
\hline Pycreus flavescens & 30.77 & Pulicaria vulgaris & 27.27 \\
\hline Juncus inflexus & 30.77 & Sonchus oleraceus & 27.27 \\
\hline Mentha pulegium & 30.77 & Tussilago farfara & 27.27 \\
\hline Lythrum salicaria & 30.77 & Bolboschoenus maritimus & 27.27 \\
\hline Gratiola officinalis & 30.77 & Cyperus fuscus & 27.27 \\
\hline Plantago major & 30.77 & Euphorbia chamaesyce & 27.27 \\
\hline Sand & & Other sediments & \\
\hline Species & $\begin{array}{c}\text { Found in } \% \text { of } \\
\text { reservoirs }\end{array}$ & Species & $\begin{array}{c}\text { Found in } \% \text { of } \\
\text { reservoirs }\end{array}$ \\
\hline Verbena officinalis & 71.43 & Mentha pulegium & 63.89 \\
\hline Cynodon dactylon & 64.29 & Verbena officinalis & 63.89 \\
\hline Echinochloa crus-galli & 64.29 & Echinochloa crus-galli & 61.11 \\
\hline Portulaca oleracea & 64.29 & Polygonum lapathifolium & 58.33 \\
\hline Xanthium strumarium & 57.14 & Portulaca oleracea & 50.00 \\
\hline Mentha pulegium & 57.14 & Cynodon dactylon & 47.22 \\
\hline Lycopus europaeus & 50.00 & Sonchus oleraceus & 44.44 \\
\hline Plantago major & 50.00 & Polygonum aviculare & 44.44 \\
\hline Polygonum lapathifolium & 50.00 & Convolvulus arvensis & 41.67 \\
\hline Sonchus oleraceus & 42.86 & Plantago major & 41.67 \\
\hline Cyperus fuscus & 42.86 & Paspalum paspaloides & 38.89 \\
\hline Juncus articulatus & 42.86 & Potentilla reptans & 38.89 \\
\hline Heleochloa alopecuroides & 42.86 & Xanthium spinosum & 36.11 \\
\hline Paspalum paspaloides & 42.86 & Cyperus fuscus & 36.11 \\
\hline Pulicaria dysenterica & 35.71 & Bidens tripartita & 33.33 \\
\hline Pulicaria vulgaris & 35.71 & Holoschoenus romanus & 33.33 \\
\hline Xanthium spinosum & 35.71 & Chrozophora tinctoria & 33.33 \\
\hline Heliotropium europaeum & 35.71 & Digitaria sanguinalis & 33.33 \\
\hline Corrigiola litoralis & 35.71 & Solanum nigrum & 33.33 \\
\hline Citrullus lanatus & 35.71 & Xanthium strumarium & 30.56 \\
\hline Flysch & \multicolumn{3}{|c|}{ Clay } \\
\hline Species & $\begin{array}{c}\text { Found in } \% \text { of } \\
\text { reservoirs }\end{array}$ & Species & $\begin{array}{c}\text { Found in } \% \text { of } \\
\text { reservoirs }\end{array}$ \\
\hline Mentha pulegium & 65.85 & Paspalum paspaloides & 76.92 \\
\hline Cynodon dactylon & 63.41 & Polygonum lapathifolium & 76.92 \\
\hline Digitaria sanguinalis & 60.98 & Lycopus europaeus & 69.23 \\
\hline Echinochloa crus-galli & 58.54 & Mentha pulegium & 69.23 \\
\hline Polygonum lapathifolium & 56.10 & Cynodon dactylon & 69.23 \\
\hline
\end{tabular}

The 1st International Electronic Conference on Biological Diversity, Ecology, and Evolution, 15-31 March 2021 
The 1st International Electronic Conference on Biological Diversity, Ecology, and Evolution, 15-31 March 2021

$\begin{array}{cccc}\text { Polygonum aviculare } & 53.66 & \text { Portulaca oleracea } & 69.23 \\ \text { Portulaca oleracea } & 51.22 & \text { Typha angustifolia } & 69.23 \\ \text { Typha angustifolia } & 51.22 & \text { Digitaria sanguinalis } & 61.54 \\ \text { Plantago major } & 46.34 & \text { Aster squamatus } & 53.85 \\ \text { Juncus articulatus } & 43.90 & \text { Cyperus fuscus } & 53.85 \\ \text { Potentilla reptans } & 43.90 & \text { Echinochloa crus-galli } & 53.85 \\ \text { Eleocharis palustris } & 41.46 & \text { Verbena officinalis } & 53.85 \\ \text { Paspalum paspaloides } & 41.46 & \text { Conyza canadensis } & 46.15 \\ \text { Pulicaria dysenterica } & 39.02 & \text { Xanthium strumarium } & 46.15 \\ \text { Euphorbia chamaesyce } & 39.02 & \text { Inula viscosa } & 46.15 \\ \text { Solanum nigrum } & 39.02 & \text { Euphorbia chamaesyce } & 46.15 \\ \text { Verbena officinalis } & 39.02 & \text { Salix alba } & 46.15 \\ \text { Solanum nigrum } & 39.02 & \text { Bidens tripartita } & 38.46 \\ \text { Verbena officinalis } & 39.02 & \text { Sonchus oleraceus } & 38.46 \\ \text { Inula britannica } & 34.15 & \text { Citrullus lanatus } & 38.46\end{array}$

Of the found species 158 (48.8\%) are connected to natural wetlands, of these, 10 belong systematically to the Isoeto-Nanojuncetea group. These species are: Blackstonia acuminata, Cyperus fuscus, Cyperus michelianus, Eleocharis acicularis, Gnaphalium uliginosum, Heliotropium supinum, Lindernia procumbens, Ludwigia palustris, Lythrum hyssopifolia, Verbena supina. Most of these species, with the exception of Cyperus taxa, proved to be very rare, several of which were found only in 1-2 reservoirs. In the drier, upper parts of the reservoirs, taxa of non-aquatic habitats were common, e.g. Cynodon dactylon and Conyza canadensis. Both ruderal and semi-ruderal elements were represented in significant numbers.

\subsection{Nature conservation assessment}

Most of the species found are not of high conservation value, 110 species were evaluated in IUCN World Red List in the LC category and 70 species were evaluated in IUCN Mediterranean Red List in the LC category. Only 1 species included in the Albanian Red List: Spirodela polyrhiza (L.) Schleid (VU). A total of 35 adventive species were found during the research, which were widespread in reservoirs, but in most cases were present only with a small cover.

\section{Discussion}

Reservoirs were surveyed on a random basis based on abiotic parameters, regional distribution, and altitude distribution. Outstanding species richness was recorded with the 324 taxa found. In these small areas $10 \%$ of Albania's flora was detected in a short single period of the growing season. After two years of drought, mud vegetation can develop in these artificial ephemeral habitats, in addition water reservoirs can be a refuge for plants that are connected to wet habitats [3]. It is also worth to mention that in the long drought of 2016-2017 xerophilous and perennial plants could colonize large parts of the reservoirs.

Research shows that by targeting certain habitat types, we can greatly increase our knowledge on the flora of a country or region.

The composition of the flora of reservoirs is determined by substrate (e.g. Eclipta prostrata (L.) L. grows on clay and Chenopodium rubrum L. grows on sand) and by altitude (e.g. Lippia nodiflora (L.) Michx. in the lower Mediterranean regions).

It has been observed that some adventive species spread regionally (e.g. Dysphania pumilio R. Br. is found only in the south).

Even if these ephemeral mudflats presence is hectic, yet plants that are connected to wetland habitats appear when the conditions are favourable for them [8]. 
In addition to experiencing high species richness, the ratio of adventive species is high, especially if we take into consideration the fact that Albania is the least infected country in Europe by aliens [28]. The reasons for this may be that these bare soil surfaces can easily be colonised by aliens [29] and grazing and manuring in and around reservoirs can help the spreading of alien (potentially invasive) species [28], but grazing can also prevents or reduces the spread of invasive plants [30].

\section{Conclusions}

Overall, we can significantly expand our knowledge of the flora of a given region through a targeted study of a habitat type. In the case of such a globally attenuating ephemeral habitat, this is of high importance. The collected records enable us to evaluate the reservoirs as ephemerous habitats in further viewpoints. Further research perspectives may include: the connection between the rate of annuals and biennials/perennials and the length of drought, and investigating the connection between the spectrum of floristic elements and the reservoir's geographical location.

Acknowledgments: We would like to thank Zoltán Nemcsok, who participated in the field work as a university student.

Author Contributions: A.R. and Z.B. conceived, designed and performed the research, analyzed the data; A.R. wrote the paper.

Conflicts of Interest: The authors declare no conflict of interest.

\section{References}

1. European Environment Agency (EEA). The European environment - state and outlook 2015: synthesis report,. European Environment Agency: Copenhagen, Denmark, 2015; 205 pp.

2. Zacharias, I.; Zamparas, M. Mediterranean temporary ponds. A disappearing ecosystem. Biodiversity and Conservation 2010, 19, 3827-3834. DOI: http://dx.doi.org/10.1007/s10531-010-9933-7.

3. Chester, E.T.; Robson, B.J. Anthropogenic refuges for freshwater biodiversity: Their ecological characteristics and management. Biological Conservation 2013, 166, 64-75. DOI: https://doi.org/10.1016/j.biocon.2013.06.016.

4. Céréghino, R.; Boix, D.; Cauchie, H.-M.; Martens, K; Oertli, B. The ecological role of ponds in a changing world. Hydrobiologia 2014, 723, 1-6. DOI: https://doi.org/10.1007/s10750-013-1719-y

5. Striers, I.; Crohain, N.; Josens, G.; Triest, L. Impact of three aquatic invasive species on native plants and macroinvertebrates in temperate ponds. Biological Invasions 2011, 13, 2715-2726. DOI: https://doi.org/10.1007/s10530-011-9942-9.

6. Šumberová, K.; Lososová, Z.; Fabšičová, M.; Horáková, V. Variability of vegetation of exposed pond bottoms in relation to management and environmental factors. Preslia 2006, 78, 235-252.

7. Salisbury, E.J. The pioneer vegetation of exposed muds and its biological features. Philosophical Transactions of the Royal Society of London. Biological Sciences 1970, 259, 207-255. DOI: https://doi.org/10.1098/rstb.1970.0059

8. Deil, U. A review on habitats, plant traits and vegetation of ephemeral wetlands - a global perspective. Phytocoenologia 2005, 35(2-3), 533-705. DOI: https://doi.org/10.1127/0340-269X/2005/0035-0533.

9. Alves-da-Silva, S.C.; Bona, C.; de Chiara Moço, M.C.; Cervi, A.C. Floristic survey and species richness of aquatic macrophytes in water supply reservoirs. Check List 2014, 10(6), 1324-1330. DOI: http://dx.doi.org/10.15560/10.6.1324.

10. Croce, A. Vascular flora of eight water reservoir areas in southern Italy. Check List 2015, 11(2), 1593. DOI: http://dx.doi.org/10.15560/11.2.1593.

11. Poschlod, P; Rosbakh, S. Mudflat species: Threatened or hidden? An extensive seed bank survey of 108 fish ponds in Southern Germany. Biological Conservation 2018, 225, 154-163. DOI: https://doi.org/10.1016/j.biocon.2018.06.024.

12. Pano, N. Pasuritë ujore të Shqipërisë; Akademia e Shkencave e Shqipërisë: Tirana, Albania, 2015; 634 pp.

13. Lushaj, B.; Hoxhaj, F.; Ndini, M.; Selenica, A.; Pambuku, A.; Dafa, I.; Hasimi, A.; Zaimi, K.; Marku, M.; Çomo, E.; Vako, E.; Isufaj, S; Myrtaj, B. General Overview of the Transboundary Waters of Rivers, Lakes, 
Groundwater and Trend of them, in Albania. Online International Interdisciplinary Research Journal 2016, 6(1), 418-446.

14. Drought Management Centre for Southeastern Europe (DMCSEE). Drought Monitoring Bulletin. Overview from February to September 2017; 2017, 15 pp. Available online: http://www.dmcsee.org/uploads/file/430 dmcsee bulletin season2017.pdf

15. Barina Z. (ed.). Distribution atlas of vascular plants in Albania; Hungarian Natural History Museum: Budapest, Hungary, 2017; 492 pp. ISBN 978-963-9877-29-0

16. Demiri, M. Flora ekskursioniste e Shqiperise. Shtëpia Botuese e Librit Shkollor: Tirana, Albania, 1983; 986 pp.

17. Paparisto, K.; Demiri, M.; Mitrushi, I; Qosja, Xh. Flora e Shqiperise. Vol. 1; Akademia e Shkencave e RPS të Shqipërisë Qendra e Kërkimeve Biologike: Tirana, Albania, 1988; 457 pp.

18. Qosja, Xh.; Paparisto, K.; Demiri, M.; Vangjeli, J.; Balza, E. Flore de l'Albanie (Flora e Shqiperise). Vol. 2; Akademia e Shkencave e Republikes se Shqiperise Qendra e Kerkimeve Biologike: Tirana, Albania, 1992; 446 pp.

19. Qosja, Xh.; Paparisto, K.; Vangjeli, J.; Ruci, B. Flore de l'Albanie (Flora e Shqiperise). Vol. 3. Akademia e Shkencave e Republikes es Shqiperise Instituti i Kerkimeve Biologjike: Tirana, Albania, 1996, 331 pp.

20. Vangjeli, J.; Ruci, B.; Mullaj, A.; Paparisto, K.; Qosja, Xh.2000. Flore de l'Albanie (Flora e Shqiperise). Vol. 4; Akademia e Shkencave e Republikes es Shqiperise Instituti i Kerkimeve Biologjike: Tirana, Albania, 2000; 502 pp.

21. Vangjeli, J. (2003): Udhëheqës fushor i florës së Sqipërisë; Akademia e Shkencave e Shqipërisë: Tirana, Albania, 2003; 598 pp.

22. Tutin, T.G.; Heywood, V.H.; Burges, N.A.; Moore, D.M.; Valentine, D.H.; Walters, S.M.; Webb, D.A. Flora Europaea. Volume 1. Lycopodiaceae to Platanaceae; Cambridge University Press: Cambridge, Great Britain, 1964; 464 pp.

23. Tutin, T.G.; Heywood, V.H.; Burges, N.A.; Moore, D.M.; Valentine, D.H.; Walters, S.M.; Webb, D.A. Flora Europaea. Volume 2. Rosaceae to Umbelliferae, 3rd ed.; Cambridge University Press: Cambridge, Great Britain, 1981; 469 pp.

24. Tutin, T.G.; Heywood, V.H.; Burges, N.A.; Moore, D.M.; Valentine, D.H.; Walters, S.M.; Webb, D.A. Flora Europaea. Volume 3. Diapensiacea to Myoporaceae; Cambridge University Press: Cambridge, Great Britain, 1972; 385 pp.

25. Tutin, T.G.; Heywood, V.H.; Burges, N.A.; Moore, D.M.; Valentine, D.H.; Walters, S.M.; Webb, D.A. Flora Europaea. Volume 4. Plantaginaceae to Compositae (and Rubiaceae); Cambridge University Press: Cambridge, Great Britain 1976; 505 pp.

26. Tutin, T.G.; Heywood, V.H.; Burges, N.A.; Moore, D.M.; Valentine, D.H.; Walters, S.M.; Webb, D.A. Flora Europaea. Volume 5. Alismataceae to Orchidaceae (Monocotyledones); Cambridge University Press: Cambridge, Great Britain 1980; 452 pp.

27. Mesterházy, A.; Matus, G.; Király, G.; Szűcs, P.; Török, P.; Valkó, O.; Pelles, G.; Papp, V.G.; Virók, V.; Nemcsok, Z.; Rigó, A.; Hohla, M; Barina, Z. Taxonomical and chorological notes 5 (59-68). Studia botanica hungarica 2017, 48(2), 263-275. DOI: https://doi.org/10.17110/StudBot.2017.48.2.263.

28. Barina, Z.; Rakaj, M.; Somogyi, G.; Erős-Honti, Z.; \& Pifkó, D. The alien flora of Albania: history, current status and future trends. Weed Research, 2014, 54(2), 196-215. DOI: https://doi.org/10.1111/wre.12061.

29. Walther, G.-R.; Roques, A.; Hulme, P.E.; Sykes, M.T.; Pyšek, P.; Kühn, I; Zobel, M.; Bacher, S.; Botta-Dukát, Z.; Bugmann, H.; Czúcz, B.; Dauber, J.; Hickler, T.; Jarošík, V.; Kenis, M.; Klotz, S.; Minchin, D.; Moora, M.; Nentwig, W.; Ott, J.; Panov, V.E.; Reineking, B.; Robinet, C.; Semenchenko, V.; Solarz, W.; Thuiller, W.; Vilà, M.; Vohland, K.; Settele, J. Alien species in a warmer world: risks and opportunities. Trends in Ecology \& Evolution 2009, 24(12), 686-693. DOI: https://doi.org/10.1016/j.tree.2009.06.008.

30. Maron, J.L.; Vilà, M. When do herbivores affect plant invasion? Evidence for the natural enemies and biotic resistance hypotheses. Oikos 2001, 95, 361-373. DOI. https://doi.org/10.1034/j.1600-0706.2001.950301.x.

(C) 2020 by the authors; licensee MDPI, Basel, Switzerland. This article is an open access article distributed under the terms and conditions of the Creative Commons by Attribution (CC-BY) license (http://creativecommons.org/licenses/by/4.0/). 